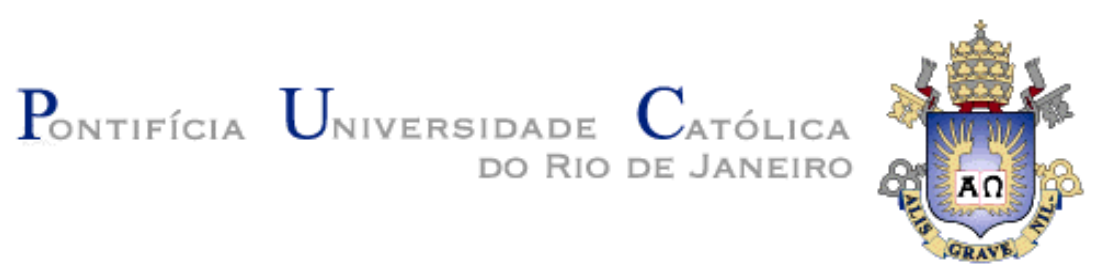

Maíra Ferreira de Noronha

Controle da Execução e Disponibilização de Dados para Aplicativos sobre Seqüências Biológicas: o Caso BLAST

Dissertação de Mestrado

Dissertação apresentada como requisito parcial para obtenção do título de Mestre pelo Programa de PósGraduação em Informática da PUC-Rio.

Orientador: Sérgio Lifschitz

Rio de Janeiro, setembro de 2006 


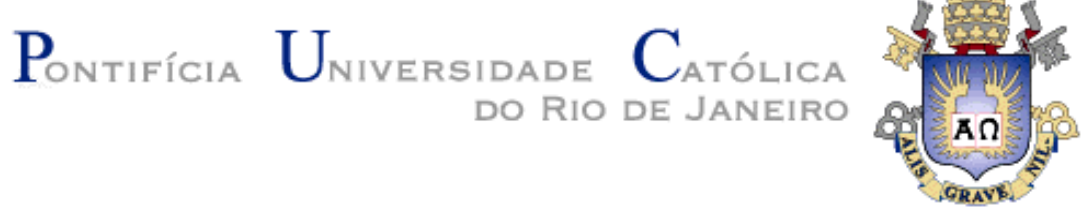

Maíra Ferreira de Noronha

\section{Controle da Execução e Disponibilização de Dados para Aplicativos sobre Seqüências Biológicas: o Caso BLAST}

Dissertação apresentada como requisito parcial para obtenção do título de Mestre pelo Programa de PósGraduação em Informática da PUC-Rio. Aprovada pela Comissão Examinadora abaixo assinada.

Prof. Sérgio Lifschitz Orientador

Departamento de Informática - PUC-Rio

Prof. Marcus Vinicius Soledade Poggi de Aragão

Departamento de Informática - PUC-Rio

Prof. Melissa Lemos Cavalieri

Departamento de Informática - PUC-Rio

Prof. Marta Lima de Queiros Mattoso COPPE - UFRJ

Prof. José Eugênio Leal Coordenador Setorial do Centro Técnico Científico - PUC-Rio 
Todos os direitos reservados. É proibida a reprodução total ou parcial do trabalho sem autorização da universidade, da autora e do orientador.

\section{Maíra Ferreira de Noronha}

Graduou-se em Engenharia de Computação na Pontifícia Universidade Católica do Rio de Janeiro em 2003. Participou do Programa de Graduação Sanduíche da CAPES de 2001 a 2002, tendo realizado um ano do curso de Informática e Matemática Aplicada no ENSEEIHT, em Toulouse, França. Trabalha atualmente como Analista de Sistemas na Petrobrás.

Ficha Catalográfica

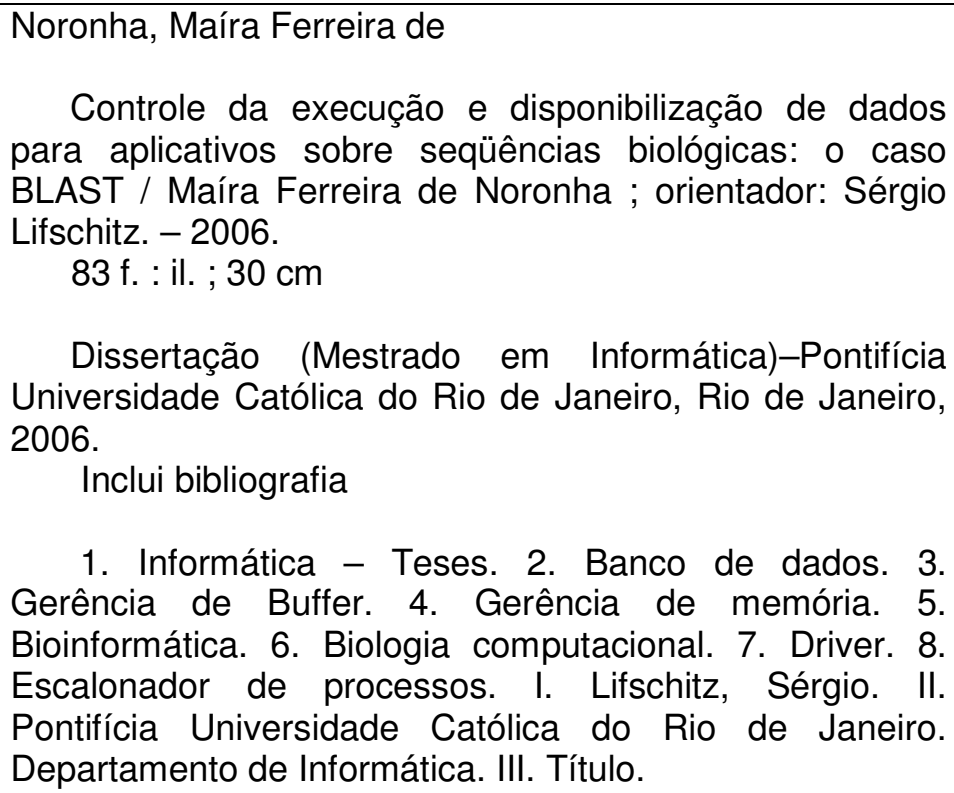

Dissertação (Mestrado em Informática)-Pontifícia Universidade Católica do Rio de Janeiro, Rio de Janeiro, 2006.

Inclui bibliografia

1. Informática - Teses. 2. Banco de dados. 3. Gerência de Buffer. 4. Gerência de memória. 5. Bioinformática. 6. Biologia computacional. 7. Driver. 8. Escalonador de processos. I. Lifschitz, Sérgio. II. Pontifícia Universidade Católica do Rio de Janeiro. Departamento de Informática. III. Título.

CDD: 004 


\section{Agradecimentos}

Ao meu orientador, Sérgio Lifschitz, pelos inúmeros conselhos, pela confiança e pela paciência demonstrada ao longo dos anos.

À minha família, da qual recebo sempre muito carinho e apoio.

Ao meu namorado Marcelo por seu carinho, incentivo e apoio incondicional em todos os momentos.

Aos meus amigos, que tornam os dias sempre alegres e especiais.

Aos meus colegas da PUC-Rio, que foram muito receptivos e tornaram agradáveis os momentos na universidade.

Ao Daniel pela ajuda em diversos momentos durante o desenvolvimento da minha dissertação.

Ao CNPQ e à PUC-Rio pelos auxílios concedidos, sem os quais este trabalho não poderia ter sido realizado. 


\section{Resumo}

Noronha, Maíra Ferreira de; Lifschitz, Sérgio. Controle da Execução e Disponibilização de Dados para Aplicativos sobre Seqüências Biológicas: o Caso BLAST. Rio de Janeiro, 2007. 83p. Dissertação de Mestrado - Departamento de Informática, Pontifícia Universidade Católica do Rio de Janeiro.

Este trabalho consiste na criação de uma ferramenta provedora de dados para o BLAST, denominada BioProvider. Esta é usada para prover dados realizando um gerenciamento de buffer eficiente para o BLAST, controlando também o escalonamento dos processos do mesmo. A comunicação entre o BioProvider e os processos do BLAST, assim como o controle de concorrência e bloqueios, é feita por meio de um driver, que substitui as chamadas a funções de leitura e escrita de arquivos do banco de dados. Deste modo, o código do BLAST não precisa ser modificado para ser realizar a comunicação com o BioProvider e este pode ser usado para diferentes versões do BLAST. O desenvolvimento do BioProvider é a primeira etapa para a criação de uma solução aplicável também a outras ferramentas de Bioinformática. Por ser transparente aos programas, a ferramenta desenvolvida é facilmente extensível, podendo ser futuramente modificada para prover dados para outros aplicativos, usar outras estratégias de gerência de buffer ou prover dados armazenados em formatos diferentes dos lidos por processos clientes, convertendo-os em tempo de execução. O BioProvider foi testado com a versão recente do NCBI BLAST, obtendo consideráveis melhoras de desempenho, e seu funcionamento foi verificado também com a versão do WU-BLAST com código aberto. Foram realizadas análises de variações no algoritmo de gerenciamento de buffer e dos fatores que influenciam o desempenho dos processos BLAST.

\section{Palavras-chave}

Bancos de Dados;Gerência de Buffer;Gerência de Memória;NCBI BLAST;WU-BLAST;Bioinformática;Biologia Computacional;Driver;Escalonador de Processos. 


\section{Abstract}

Noronha, Maíra Ferreira de; Lifschitz, Sérgio. Controle da Execução e Disponibilização de Dados para Aplicativos sobre Seqüências Biológicas: o Caso BLAST. Rio de Janeiro, 2007. 83p. Dissertação de Mestrado - Departamento de Informática, Pontifícia Universidade Católica do Rio de Janeiro.

This work consists on the creation of a tool named BioProvider to provide data to BLAST. The tool provides the data using buffer management techniques that are efficient for BLAST and controls process scheduling. The communication between BioProvider and the BLAST processes, as well as the concurrency and blocking control, is done through a device driver that substitutes the read and write function calls to the database files. By this means, the application code can remain unchanged and BioProvider can be used with different versions of BLAST. The development of BioProvider was the first stage to the creation of a solution that can be applied as well to other Bioinformatics tools. Due to its transparency in the view of other applications, BioProvider can be easily extended in the future to provide data to other applications, to use other buffer management techniques or to provide data stored in different formats of those read by the client processes, converting the data in runtime. BioProvider has been tested with the most recent version of NCBI BLAST and considerable improvement has been verified. The tool has been shown to work as well with the open source version of WU-BLAST. Some variations on the buffer management algorithm were studied, as well as the different factors that influence the performance of BLAST processes.

\section{Keywords}

Databases;Buffer Management;Memory Management;NCBI BLAST;WUBLAST;Bioinformatics;Computational Biology;Driver;Data Scheduler. 


\section{Sumário}

1 Introdução

2 Contexto e Motivações 16

$\begin{array}{lr}\text { 2.1. A Família BLAST } & 17\end{array}$

$\begin{array}{lr}\text { 2.1.1. Principais Características } & 18\end{array}$

$\begin{array}{lr}\text { 2.1.2. Subprogramas } & 19\end{array}$

2.2. Formatos dos Bancos de Dados 20

2.2.1. O Banco de Dados do NCBI BLAST 21

2.2.2. O Banco de Dados do WU-BLAST 23

2.3. O Acesso do BLAST ao Banco de Dados 24

2.3.1. NCBI BLAST com 1 Seqüência de Entrada 24

2.3.2. NCBI BLAST com 5 Seqüências de Entrada 26

2.3.3. WU-BLAST com 1 Seqüência de Entrada 27

2.4. Trabalhos de Melhoria do BLAST 27

2.4.1. Gerenciamento de Buffer para o BLAST 29

2.4.2. Gerenciamento de Buffer Não-Intrusivo 31

2.5. Considerações Finais 32

3 O BioProvider 34

3.1. A Estratégia Utilizada 35

3.1.1. Gerenciamento de Buffer 36

3.1.2. Tratamento do Banco de dados 37

3.1.3. Melhorias no Desempenho 40 
3.2. Implementação 43

3.3. Considerações Finais 47

4 Resultados Obtidos 48

4.1. Variação do Tamanho da Memória 50

4.2. Variação do Tamanho do Anel em Memória 52

4.3. Variação das Seqüências de Entrada 55

4.4. Variação do Número de Blocos 57

4.5. Variação da Estratégia de Atendimento dos Processos 60

4.6. Considerações Finais 62

5 Conclusões $\quad 64$

5.1. Trabalhos Futuros 65

$\begin{array}{ll}\text { Referências Bibliográficas } & 67\end{array}$

$\begin{array}{ll}\text { A Funcionamento do BLAST } & 70\end{array}$

B Gerência de Memória em Bancos de Dados 73

C Drivers de Dispositivos para o Linux $\quad 75$

C.1. Números Maior e Menor 76

C.2. Operações em um Arquivo Especial 77

C.3. Alocação de Memória 79

C.4. Execução de Tarefas 79

C.4.1. Execução em resposta a uma solicitação de um processo 80

C.4.2. Execução em resposta a interrupções 80

C.4.3. Execução espontânea 81

$\begin{array}{ll}\text { C.5. Controle de Concorrência } & 81\end{array}$ 
C.6. Bloqueio de Processos 82

C.7. Estrutura Básica de um Módulo do Linux 82 


\section{Lista de figuras}

Figura 1: Leitura realizada pelo NCBI BLAST com 1 seqüência de entrada 25

Figura 2: Leitura realizada pelo NCBI BLAST com 5 seqüências de entrada 26

Figura 3: Leitura realizada pelo WU-BLAST com 1 seqüência de entrada 27

Figura 4: Acesso dos processos BLAST às páginas do anel em memória 29

Figura 6: Erro dos ponteiros do arquivo de índices. 38

Figura 7: Pré-formatação do banco de dados 39

Figura 8: Gráfico dos tempos médios, teste 1

Figura 9: Gráfico dos tempos totais, teste 1

Figura 10: Gráfico dos números de page faults, teste 1

Figura 11: Gráfico dos números de mudanças de contexto, teste 1

Figura 12: Gráfico dos tempos médios, teste 2

Figura 13: Gráfico dos tempos totais, teste 2

Figura 14: Gráfico dos números de page faults, teste 2

Figura 15: Gráfico dos números de mudanças de contexto, teste 2

Figura 16: Gráfico dos tempos médios, teste 3

Figura 17: Gráfico dos tempos totais, teste 3

Figura 18: Gráfico dos números de page faults, teste 3

Figura 19: Gráfico dos números de mudanças de contexto, teste 3

Figura 20: Gráfico dos tempos médios, teste $4 \quad 58$

Figura 21: Gráfico dos tempos totais, teste 4

Figura 22: Gráfico dos números de page faults, teste 4

Figura 23: Gráfico dos números de mudanças de contexto, teste 4 
Figura 24: Gráfico dos tempos médios, teste 5 61

Figura 25: Gráfico dos tempos totais, teste 5 61

Figura 26: Gráfico dos números de page faults, teste 5

Figura 27: Gráfico dos números de mudanças de contexto, teste 5 


\section{Lista de tabelas}

Tabela 1: Códigos dos caracteres de aminoácidos do NCBI 2.0

Tabela 2: Códigos dos caracteres de aminoácidos do WU-BLAST 1.4

Tabela 3: Variáveis usadas nos testes e seus valores 49

Tabela 4: Valores das variáveis no teste 1

Tabela 5: Valores das variáveis no teste 2

Tabela 6: Valores das variáveis no teste 3

Tabela 7: Valores das variáveis no teste $4 \quad 58$

$\begin{array}{ll}\text { Tabela 8: Valores das variáveis no teste 5 } & 60\end{array}$ 